\title{
PERSEPSI ANTARA TENAGA KERJA PENDATANG LAKI- LAKI DAN PEREMPUAN TERHADAP PUSH AND PULL FACTORS
}

\author{
Septiani Riwanti ${ }^{1}$ ), Dwi Kartikasari ${ }^{2}$ ) \\ 1) Prodi Administrasi Bisnis Terapan, Politeknik Negeri Batam, Batam, Indonesia, \\ Email: septianiriwanti@gmail.com \\ 2) Prodi Administrasi Bisnis Terapan, Politeknik Negeri Batam, Batam, Indonesia, \\ Email: dkartika414@gmail.com
}

\begin{abstract}
This research is aimed to know the difference of perception between National Migrant Workers of Men And Women Against Push And Pull Factors. The variable of push factors used in this research is that of job field, low wage, seeking capital and necessity of life. And pull factors are job opportunities, high wages, distance and culture. Then the data is processed using SPSS 20 software with parametric metode that is independent sample t test. The result of the research revealed that there is no difference of perception between men and women on the job field (push factor), there is no difference of perception between men and women to low wages (push factor), there is no difference of perception between men and women against looking for capital (push factor), there are differences of perceptions between men and women on the necessity of life (push factor), there are differences of perceptions between man and woman to job opportunity (pull factor), there are differences of perceptions between men (pull factor), there are differences in perceptions between men and women on the distance factor (pull factor) and there are differences in perceptions between men and women to the pull factor.
\end{abstract}

Keywords: Labor, National Migrant Workers, Gender, Push and Pull Factors

\begin{abstract}
Abstrak
Penelitian ini bertujuan untuk mengetahui perbedaan Persepsi Antara Tenaga Kerja Pendatang Laki-Laki Dan Perempuan Terhadap Push And Pull Factors. Variabel push factors yang digunakan dalam penelitian ini adalah yaitu lapangan pekerjaan, upah rendah, mencari modal dan kebutuhan hidup. Serta pull factors yaitu kesempatan kerja, upah tinggi, jarak dan budaya. Lalu Pengolahan Data yang digunakan adalah metode parametrik yaitu independent sample $t$ test. Hasil penelitian menyatakan bahwa tidak terdapat perbedaan persepsi antara tenaga kerja pendatang laki-laki dan perempuan terhadap lapangan pekerjaan (push factor), tidak terdapat perbedaan persepsi antara tenaga kerja pendatang laki-laki dan perempuan terhadap upah rendah (push factor), tidak terdapat perbedaan persepsi antara tenaga kerja pendatang laki-laki dan perempuan terhadap mencari modal (push factor), terdapat perbedaan persepsi antara tenaga kerja pendatang laki-laki dan perempuan terhadap kebutuhan hidup (push factor), terdapat perbedaan persepsi antara tenaga kerja pendatang laki-laki dan perempuan terhadap kesempatan kerja (pull factor), terdapat perbedaan persepsi antara tenaga kerja pendatang laki-laki dan perempuan terhadap upah tinggi (pull factor), terdapat
\end{abstract}


perbedaan persepsi antara tenaga kerja pendatang laki-laki dan perempuan terhadap jarak (pull factor), dan terdapat perbedaan persepsi antara tenaga kerja pendatang laki-laki dan perempuan terhadap kesamaan budaya (pull factor).

Kata kunci: Tenaga Kerja, Tenaga Kerja Pendatang, Jenis Kelamin, Push and Pull Factors. 
Septiani Riwanti \& Dwi Kartikasari, Persepsi Antara Tenaga Kerja Pendatang...

\section{PENDAHULUAN}

Sebagai salah satu kota di provinsi Kepulauan Riau, kota Batam yang memiliki jumlah populasi 1.283.196 (BPS, 2017) kenyataannya masih banyak didatangi para pencari kerja dari seluruh penjuru Indonesia. Mereka datang ke kota Batam sebagai pendatang untuk mengadu nasib serta mencari penghasilan yang mana nantinya penghasilan tersebut mereka gunakan untuk keperluan sehari-hari selama bekerja dan sebagiannya akan diberikan kepada keluarga maupun sanak saudara yang ada di kampung halaman.

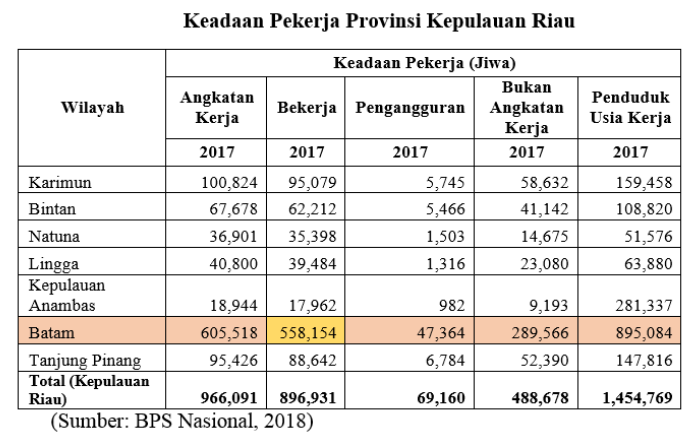

Dari tabel di atas dapat disimpulkan bahwa diantara kota/kabupaten yang ada di Kepulauan Riau, Kota Batam menjadi kota tertinggi dengan jumlah orang yang bekerja. Hal ini dikarenakan adanya push factors atau faktor pendorong dan pull factors atau faktor penarik.

Seperti yang kita ketahui, beberapa faktor penarik dari daerah tujuan menjadikan alasan untuk mereka merantau ke Batam, ditambah dengan faktor pendorong dari daerah asal yang tidak dapat memberikan mereka penghidupan yang lebih baik. Contohnya pada tahun ini besaran UMK sudah mencapai angka sebesar $\mathrm{Rp}$ 3.523.427. Artinya, sebagai kota di provinsi Kepri yang memiliki besaran UMK tertinggi, hal ini menjadi salah satu faktor penarik bagi para pendatang untuk bekerja di Batam. Kemudian beberapa faktor penarik lain yang juga menjadi alasan bagi pendatang untuk ke Batam seperti jarak yang dekat dari daerah mereka, kesamaan budaya, dan lan-lain.
Kota Batam menjadi kota terbanyak yang didatangi tenaga kerja di provinsi Kepulauan Riau ini memiliki luas lebih kurang $415 \mathrm{Km}$, terletak $20 \mathrm{Km}$ disebelah tenggara Singapura yang telah dikembangkan sejak tahun 1970 berdasarkan Kepres No. 65 tahun 1970 tanggal 19 Oktober 1970.

Gender diartikan sebagai perbedaan dalam hal peran, fungsi, status dan tanggung jawab pada laki-laki dan perempuan sebagai hasil dari bentukan atau formasi sosial budaya yang tertanam lewat proses sosialisasi dari satu generasi ke generasi selanjutnya. Terdapat dua kelompok atau golongan yang mendefinisikan gender secara berbeda. Kelompok yang pertama ialah sekelompok feminis yang mengatakan bahwa perbedaan jenis kelamin tidak menyebabkan perbedaan peran dan perilaku gender dalam tataran sosial. Kelompok kedua menganggap bahwa perbedaan jenis kelamin akan menyebabkan perbedaan perlakuan atau peran berdasarkan gender. Misalnya, ada perlakuan khusus pada pekerja wanita karena kondisi biologisnya, seperti cuti hamil, cuti haid, pemberian jam kerja malam, dan sebagainya.

Adapun rumusan masalah yang akan diteliti ialah bagaimana perbedaan persepsi antara tenaga kerja pendatang laki-laki dan perempuan terhadap 4 faktor pendorong yaitu lapangan pekerjaan, upah rendah, mencari modal, kebutuhan hidup dan 4 faktor penarik yaitu kesempatan kerja, upah tinggi, jarak serta kesamaan budaya. Tujuan penelitian ini ialah untuk mengetahui bagaimana perbedaan persepsi antara tenaga kerja pendatang laki-laki dan perempuan terhadap 4 faktor pendorong yaitu lapangan pekerjaan, upah rendah, mencari modal, kebutuhan hidup dan 4 faktor penarik yaitu kesempatan kerja, upah tinggi, jarak serta kesamaan budaya.

Beberapa penelitian terdahulu seperti pada penelitian (Felicidad, 2016) yang membahas push and pull factor tenaga kerja Filiphina migrasi di Bahrain. Hasil penelitian menunjukkan bahwa tidak 
terdapat hubungan yang signifikan antara faktor-faktor pendorong dan namun terdapat hubungan yang signifikan antara faktorfaktor penarik dalam migrasi tenaga kerja Filiphina di Bahrain. Kemudian pada penelitian (Puspitawati, 2010) tentang persepsi peran gender terhadap pekerjaan domestik dan publik pada mahasiswa IPB menunjukkan bahwa perempuan dipersepsikan masyarakat sebagai aktor yang berperan sebagaii figur ekspresif dan lakilaki dipersepsikan sebagai figur instrumental. Setelah itu penelitian oleh Munanto (2014) memiliki judul "Analisis Faktor-Faktor yang Mempengaruhi Tenaga Kerja di Jawa Tengah". Alat analisis yang digunakan ialah analisis regresi berganda dengan metode Ordinary Last Square. Hasil penelitian menunjukkan bahwa variabel produk domestik regional bruto berpengaruh signifikan dan positif terhadap tenaga kerja, variabel indeks pembangunan manusia berpengaruh signifikan dan positif terhadap tenaga kerja, serta variabel upah minimum kabupaten berpengaruh signifikan dan negatif terhadap tenaga kerja.

Harapannya penelitian ini dapat memberi manfaat bagi pihak-pihak terkait sebagai berikut:

1. Bagi pemerintah kota Batam adalah agar hasil penelitian ini dapat berfungsi sebagai suatu alternatif pondasi pemikiran bagi pemerintah Kota Batam dalam rangka pengidentifikasian mengenai perbedaan persepsi antara lakilaki dan perempuan terhadap push and full factors.

2. Bagi pembaca yang melakukan penelitian serupa, maka penelitian ini dapat menjadi bahan pertimbangan maupun patokan bagi penelitiannya.

3. Bagi penulis, dapat menjadi referensi tambahan tekait dengan analisis perbandingan push and pull factors tenaga kerja luar Batam berdasarkan gender.

\section{KAJIAN PUSTAKA \\ Tenaga Kerja}

Menurut UU Ketenagakerjaan No.13 tahun 2003 Bab 1 pasal 1 ayat 2, tenaga kerja adalah setiap orang yang mampu melakukan pekerjaan guna menghasilkan barang dan atau jasa baik untuk memenuhi kebutuhan sendiri maupun untuk masyarakat. Penduduk yang memasuki usia kerja adalah mereka yang berusia antara 1564 tahun.

BPS (Badan Pusat Statistik) membagi tenaga kerja (employed), yaitu:

1. Tenaga kerja penuh (full employed), adalah tenaga kerja yang mempunyai jumlah jam kerja > 35 jam dalam seminggu dengan hasil kerja tertentu sesuai dengan uraian tugas;

2. Tenaga kerja tidak penuh atau setengah pengangguran (under employed), adalah tenaga kerja dengan jam kerja $<35$ jam seminggu; dan

3. Tenaga kerja yang belum bekerja atau sementara tidak bekerja (unemployed), adalah tenaga kerja dengan jam kerja $0>$ 1 jam perminggu. Menurut undangundang No 13 Tahun 2003 Tentang Ketenagakerjaan.

\section{Tenaga Kerja Pendatang}

Tenaga kerja pendatang identik dengan perpindahan orang-orang dari suatu daerah dari daerah lain yang memiliki peluang untuk mendapatkan penghidupan yang lebih baik atau biasanya disebut dengan pekerja migran. Banyak teori yang membahas mengenai pekerja migran namun hanya berkaitan dengan migran internasional, bahkan sudah dibentuk UU sendiri yakni UU No.18 Tahun 2017 tentang Pelindungan Pekerja Migran Indonesia. Sementara untuk pekerja migran lokal/nasional cukup sulit untuk menemukan penelitian berkaitan dengan ini. Menurut Fattah \& Sanusi (2008), migrasi lokal/nasional merupakan perpindahan penduduk dari suatu daerah ke daerah lain yang masih dalam satu negara. Bentuk-bentuk migrasi lokal pun dapat dibedakan menjadi beberapa macam, seperti: 
Septiani Riwanti \& Dwi Kartikasari, Persepsi Antara Tenaga Kerja Pendatang...

1. Sirkulasi, merupakan perpindahan penduduk yang tidak menetap, namun ada juga yang menetap atau tinggal sementara waktu di daerah tujuan.

2. Urbanisasi, merupakan perpindahan penduduk dari desa ke kota dalam satu pulau, dan umumnya penduduk akan menetap.

3. Ruralisasi, yakni kebalikan dari urbanisasi, ialah perpindahan penduduk dari kota ke desa.

4. Transmigrasi, adalah perpindahan penduduk dari daerah atau pulau yang penuh penduduknya ke daerah (pulau yang berpenduduk jarang.

\section{Push And Pull Factors}

Lee (1996) dalam Armoyu (2009) menyatakan perspektif migrasi dari sisi faktor penarik dan pendorong atau push-pull factors, bahwa penyebab dari seseorang melakukan kegiatan migrasi dari satu daerah ke daerah yang lain ialah karena adanya faktor ganda. Faktor ganda tersebut dipecah menjadi faktor pendorong berasal dari daerah asal dan faktor penarik berasal dari daerah tujuannya. Kemudian Lee (1978) memecah faktor-faktor tersebut menjadi 4 sub besar:

1. Kondisi yang terdapat di daerah asal

2. Kondisi yang terdapat di daerah tujuan

3. Faktor penghalang yang menghambat

4. Faktor psikologis migran

Menurut Felicidad (2016) terdapat dua jenis faktor yang dapat menentukan migrasi yakni faktor-faktor yang mendorong (push factors) dan faktor-faktor yang menarik (pull factors). Adapun yang lebih jelasnya sebagai berikut:

1. Sempitnya lapangan pekerja di daerah asal, sehingga membuat penduduk termotivasi untuk melakukan mobilitas (Primawati, 2011)

2. Upah yang rendah, yang akhirnya mendorong penduduk desa melakukan mobilitas dengan angan mendapatkan upah yang lebih tinggi daripada di daerah asalnya (Primawati, 2011)

3. Mencari modal (Primawati, 2011)
4. Memenuhi kebutuhan hidup (Primawati, 2011)

5. Kesempatan kerja yang lebih luas di daerah tujuan pendatang (Felicidad, 2016)

6. Upah tenaga kerja yang lebih tinggi di daerah tujuan (Primawati, 2011)

7. Jarak yang dekat (Susilo, 2016)

8. Kesamaan Budaya (Susilo, 2016)

Gender

Gender menurut Kementrian

Pemberdayaan Perempuan (2004) dalam Puspitawati (2010) adalah perbedaan peran, fungsi, persifatan, kedudukan, tanggung jawab dan hak perilaku, baik perempuan, maupun laki-laki yang dibentuk, dibuat, dan disosialisasikan oleh norma, adat kebiasaan, dan kepercayaan masyarakat setempat. Menurut Megawangi (1999) dalam Puspitawati (2010) terdapat dua kelompok atau golongan yang mendefinisikan gender secara berbeda. Kelompok yang pertama adalah sekelompok feminis yang mengatakan bahwa perbedaan jenis kelamin tidak menyebabkan perbedaan peran dan perilaku gender dalam tataran sosial. Kelompok kedua menganggap bahwa perbedaan jenis kelamin akan menyebabkan perbedaan perlakuan atau peran berdasarkan gender. Misalnya, ada perlakuan khusus pada pekerja wanita karena kondisi biologisnya, seperti cuti hamil, cuti haid, pemberian jam kerja malam, dan sebagainya.

Menurut Mulia (2004) dalam Ayu (2014) indikator gender terbagi dalam tiga hal, yakni:

1. Perilaku, yakni mengenai perbedaan tingkah laku atasan pria dan wanita.

2. Peran, merupakan ideology gender di masa lalu dan masa sekarang.

3. Karakteristik emosional, yaitu mengenai sifat atasan pria dan wanita dalam membimbing bawahannya.

\section{KERANGKA PEMIKIRAN}

Berdasarkan perumusan masalah dan kajian empiris yang telah dilakukan sebelumnya, maka kerangka pemikiran dalam penelitian ini yaitu : 


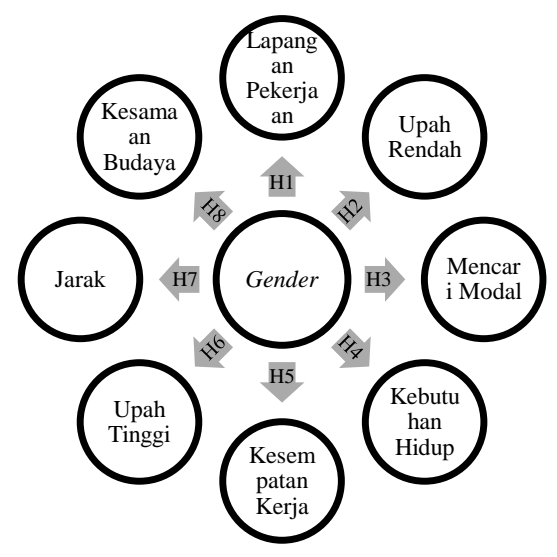

\section{METODE}

\section{Jenis Penelitian}

Desain/jenis penelitian yang digunakan penelitian ini ialah penelitian kuantitatif. Kuantitatif menurut Sugiyono (2013) ialah metode penelitian yang berlandaskan pada filsafat positivisme, digunakan untuk meneliti pada populasi dan sampel tertentu, teknik pengambilan sampel yang dilakukan secara random, dan pengumpulan data menggunakan instrumen penelitian. Pendekatan kuantitatif berfungsi untuk menguji teori, membangun fakta, memberikan statistik deskripsi, menaksir, serta meramalkan hasilnya. Kemudian penelitian apapun yang menggunakan pendekatan kuantitatif harus terstruktur, baku, formal, dan dirancang dengan matang sebelumnya. Desain juga harus bersifat spesifik dan detail karena desain adalah suatu rancangan penelitian yang akan dieksekusi secara nyata.

\section{Objek dan Ruang Lingkup Penelitian}

Dalam penulisan proposal ini penulis memilih objek penelitian pada tenaga kerja pendatang dari luar kota Batam, karena sampai saat ini Batam masih menjadi salah satu kota di Kepulauan Riau incaran para pendatang dari berbagai daerah di Indonesia. Adapun yang tenaga kerja pendatang yang digunakan dalam penelitian ini ialah mereka yang bekerja pada sektor manufaktur (industri), perkantoran, pendidikan, jasa dan perdagangan yang ada di kota Batam.

\section{Populasi dan Sampel}

Sugiyono (2013) menyatakan bahwa populasi merupakan wilayah generalisasi yang terdiri dari objek maupun subjek yang memiliki kuantitas dan karakteristik tertentu yang diputuskan oleh peneliti untuk dipelajari lalu kemudian ditarik kesimpulan akhirnya. Pada penelitian ini jumlah tenaga kerja pendatang lokal yang bekerja atau bermukim di Batam tidak diketahui pasti sehingga untuk dapat menghitung jumlah sampel minimum yang dibutuhkan menggunakan penelitian seperti cross sectional atau biasa dikenal dengan rumus (Lemeshow, 1997) dalam (Anggraini, 2009) untuk populasi yang tidak diketahui. Adapun rumusnya sebagai berikut:

$$
n=\frac{Z^{2} \times P(1-P)}{d^{2}}
$$

$$
\begin{aligned}
& \text { Keterangan : } \\
& n=\text { Jumlah sampel } \\
& \mathrm{Z}=\text { skor } \mathrm{z} \text { pada tingkat kepercayaan } 95 \% \\
& \text { yaitu } 1,96 \\
& \mathrm{P}=\text { maksimal estimasi }=50 \% \\
& d=\text { tingkat ketelitian }=10 \%
\end{aligned}
$$

Berdasarkan rumus tersebut maka $n$ yang didapat ialah 96,04 atau dibulatkan menjadi 100 orang, sehingga bisa disimpulkan bahwa dalam penelitian ini penulis harus mengambil data dari sampel minimal 100 orang.

\section{Teknik Pengumpulan Data}

Untuk mendapatkan data yang dibutuhkan dalam melakukan analisis terhadap pembuktian sementara atau yang dikenal dengan hipotesis dari permasalahan yang diajukan, maka teknik penelitian yang penulis gunakan dalam penelitian ini ialah dengan menyebarkan kuesioner kepada responden untuk diisi yang mana kuesioner ini berisi beberapa pertanyaan yang berkaitan dengan penelitian ini. 
Septiani Riwanti \& Dwi Kartikasari, Persepsi Antara Tenaga Kerja Pendatang...

\section{METODE ANALISIS DATA}

Metode analisis yang digunakan untuk menganalisis data yang diperoleh sekaligus untuk menguji hipotesis yang telah diajukan dalam penelitian ini adalah sebagai berikut:

1. Analisis deskriptif adalah analisis yang dilakukan untuk mengetahui data dari sampel populasi yang diteliti, khususnya karakteristik responden, yang berisi mengenai Umur, Pendapatan, Jenis Kelamin, Pendidikan Terakhir, Status Pernikahan, Kota Asal/Provinsi, Pekerjaan Sebelumnya, Pekerjaan di Batam dan Lokasi Bekerja. Kemudian jawaban responden yang berisi mengenai frekuensi tanggapan responden atas pertanyaan yang diajukan di dalam kuesioner serta pembahasan hasil kuesioner yang berisi mengenai kuesioner yang telah diisi oleh responden.

2. Statistik Inferensial adalah statistik yang menganalisis data sampel yang kemudian menarik kesimpulan dari hasil analisis tersebut hingga dapat digeneralisasikan ke data induk.

3. Pengujian yang digunakan pada penelitian ini adalah Uji Independent Sample $T$ Test. Menurut Sugiyono (2013) mengatakan bahwa statistik parametris yang digunakan untuk menguji hipotesis komparatif rata-rata dua sampel apabila datanya berbentuk interval atau ratio maka menggunakan ttest. Analisa t-test menurut Wahyono (2012) ialah analisa yang digunakan untuk menguji dua rata-rata dari dua sampel yang tidak saling berkaitan. Penentuan kesimpulannya berdasarkan signifikasi sebagai berikut:

1. Signifikansi < 0.05 , maka Ho ditolak da $\mathrm{n}$ Ha diterima

2. Signifikansi > 0.05, maka Ho diterima dan Ha ditolak

\section{Uji Hipotesis}

Berikut ini peneliti ajukan beberapa hipotesis yang dibuat berdasarkan uji komparatif independent sample t test:
1. Pengujian Hipotesis 1 (Lapangan Pekerjaan)

Ho : Tidak terdapat perbedaan persepsi antara tenaga kerja pendatang laki-laki dan perempuan terhadap lapangan pekerjaan

H1 : Terdapat perbedaan persepsi antara tenaga kerja pendatang laki-laki dan perempuan terhadap lapangan pekerjaan

2. Pengujian Hipotesis 2 (Upah Rendah) Ho : Tidak terdapat perbedaan persepsi antara tenaga kerja pendatang laki-laki dan perempuan terhadap upah rendah

H1 : Terdapat perbedaan persepsi persepsi antara tenaga kerja pendatang laki-laki dan perempuan terhadap upah rendah

3. Pengujian Hipotesis 3 (Mencari Modal) Ho : Tidak terdapat perbedaan persepsi antara tenaga kerja pendatang laki-laki dan perempuan terhadap mencari modal H1 : Tedapat perbedaan persepsi antara tenaga kerja pendatang laki-laki dan perempuan terhadap mencari modal

4. Pengujian Hipotesis 4 (Kebutuhan Hidup)

Ho : Tidak terdapat perbedaan persepsi antara tenaga kerja pendatang laki-laki dan perempuan terhadap kebutuhan hidup

H1 : Terdapat perbedaan persepsi antara tenaga kerja pendatang laki-laki dan perempuan terhadap kebutuhan hidup

5. Pengujian Hipotesis 5 (Kesempatan Kerja)

Ho : Tidak terdapat perbedaan persepsi antara tenaga kerja pendatang laki-laki dan perempuan terhadap kesempatan kerja

H1 : Terdapat perbedaan persepsi antara tenaga kerja pendatang laki-laki dan perempuan terhadap kesempatan kerja

6. Pengujian Hipotesis 6 (Upah Tinggi)

Ho : Tidak terdapat perbedaan persepsi antara tenaga kerja pendatang laki-laki dan perempuan terhadap upah tinggi H1 : Terdapat perbedaan persepsi antara tenaga kerja pendatang laki-laki dan perempuan terhadap upah tinggi 
7. Pengujian Hipotesis 7 (Jarak)

Ho : Tidak terdapat perbedaan persepsi antara tenaga kerja pendatang laki-laki dan perempuan terhadap jarak

H1 : Terdapat perbedaan persepsi antara tenaga kerja luar pendatang laki-laki dan perempuan terhadap jarak

8. Pengujian Hipotesis 8 (Kesamaan Budaya)

Ho : Tidak terdapat perbedaan persepsi antara tenaga kerja pendatang laki-laki dan perempuan terhadap kesamaan budaya

H1 : Terdapat perbedaan persepsi antara tenaga kerja pendatang laki-laki dan perempuan terhadap kesamaan budaya

\section{HASIL DAN PEMBAHASAN Hasil Uji Validitas}

Penelitian ini melakukan uji validitas menggunakan program SPSS 20 dengan melihat masing-masing skor indikator melalui korelasi bivariate. Nilai $r$ hitung diperoleh dari output SPSS pada baris paling atas dengan melihat nilai Pearson Correlation sedangkan nilai $\mathrm{r}$ tabel dilihat dari tabel signifikansi Alpha 5\% yaitu sebesar 0,195. Nilai $\mathrm{N}$ adalah banyaknya responden yaitu 100 responden yang telah mengisi kuesioner yang berisi 28 pertanyaan.

\begin{tabular}{|c|l|c|c|c|}
\hline \multicolumn{5}{|c|}{ Validitas } \\
\hline Variabel & Item & $\begin{array}{c}\mathrm{r} \\
\text { hitung }\end{array}$ & $\mathrm{r}$ tabel & $\begin{array}{c}\text { Kesimpu } \\
\text { lan }\end{array}$ \\
\hline $\begin{array}{l}\text { Lapangan } \\
\text { Pekerjaan }\end{array}$ & $\begin{array}{l}\text { Item } \\
1\end{array}$ & 0,684 & 0,195 & Valid \\
\cline { 2 - 5 } & $\begin{array}{l}\text { Item } \\
2\end{array}$ & 0,630 & 0,195 & Valid \\
\cline { 2 - 5 } & $\begin{array}{l}\text { Item } \\
3\end{array}$ & 0,818 & 0,195 & Valid \\
\cline { 2 - 5 } & $\begin{array}{l}\text { Item } \\
4\end{array}$ & 0,741 & 0,195 & Valid \\
\hline \multirow{5}{*}{ Upah } & $\begin{array}{l}\text { Item } \\
1\end{array}$ & 0,519 & 0,195 & Valid \\
\cline { 2 - 5 } & $\begin{array}{l}\text { Item } \\
2\end{array}$ & 0,740 & 0,195 & Valid \\
\cline { 2 - 5 } & $\begin{array}{l}\text { Item } \\
3\end{array}$ & 0,704 & 0,195 & Valid \\
\cline { 2 - 5 } & $\begin{array}{l}\text { Item } \\
4\end{array}$ & 0,766 & 0,195 & Valid \\
\hline
\end{tabular}

\begin{tabular}{|c|c|c|c|c|}
\hline \multirow{3}{*}{$\begin{array}{l}\text { Mencari } \\
\text { Modal }\end{array}$} & $\begin{array}{l}\text { Item } \\
1\end{array}$ & 0,642 & 0,195 & Valid \\
\hline & $\begin{array}{l}\text { Item } \\
2\end{array}$ & 0,620 & 0,195 & Valid \\
\hline & $\begin{array}{l}\text { Item } \\
3\end{array}$ & 0,672 & 0,195 & Valid \\
\hline \multirow[t]{3}{*}{$\begin{array}{l}\text { Kebutuhan } \\
\text { Hidup }\end{array}$} & $\begin{array}{l}\text { Item } \\
1\end{array}$ & 0,770 & 0,195 & Valid \\
\hline & $\begin{array}{l}\text { Item } \\
2 \\
\end{array}$ & 0,785 & 0,195 & Valid \\
\hline & $\begin{array}{l}\text { Item } \\
3 \\
\end{array}$ & 0,596 & 0,195 & Valid \\
\hline \multirow[t]{4}{*}{$\begin{array}{l}\text { Kesempatan } \\
\text { Kerja }\end{array}$} & $\begin{array}{l}\text { Item } \\
1\end{array}$ & 0,654 & 0,195 & Valid \\
\hline & $\begin{array}{l}\text { Item } \\
2\end{array}$ & 0,819 & 0,195 & Valid \\
\hline & $\begin{array}{l}\text { Item } \\
3\end{array}$ & 0,753 & 0,195 & Valid \\
\hline & $\begin{array}{l}\text { Item } \\
4\end{array}$ & 0,633 & 0,195 & Valid \\
\hline \multirow[t]{3}{*}{$\begin{array}{l}\text { Upah } \\
\text { Tinggi }\end{array}$} & $\begin{array}{l}\text { Item } \\
1 \\
\end{array}$ & 0,712 & 0,195 & Valid \\
\hline & $\begin{array}{l}\text { Item } \\
2 \\
\end{array}$ & 0,853 & 0,195 & Valid \\
\hline & $\begin{array}{l}\text { Item } \\
3 \\
\end{array}$ & 0,777 & 0,195 & Valid \\
\hline \multirow[t]{4}{*}{ Jarak } & $\begin{array}{l}\text { Item } \\
1\end{array}$ & 0,907 & 0,195 & Valid \\
\hline & $\begin{array}{l}\text { Item } \\
2\end{array}$ & 0,927 & 0,195 & Valid \\
\hline & $\begin{array}{l}\text { Item } \\
3 \\
\end{array}$ & 0,927 & 0,195 & Valid \\
\hline & $\begin{array}{l}\text { Item } \\
4\end{array}$ & 0,943 & 0,195 & Valid \\
\hline \multirow[t]{3}{*}{$\begin{array}{l}\text { Kesamaa } \\
\text { n Budaya }\end{array}$} & $\begin{array}{l}\text { Ite } \\
\mathrm{m} 1\end{array}$ & $\begin{array}{l}0,63 \\
3 \\
\end{array}$ & $\begin{array}{l}0,19 \\
5 \\
\end{array}$ & Valid \\
\hline & $\begin{array}{l}\text { Ite } \\
\mathrm{m} 2\end{array}$ & $\begin{array}{l}0,86 \\
5 \\
\end{array}$ & $\begin{array}{l}0,19 \\
5 \\
\end{array}$ & Valid \\
\hline & $\begin{array}{l}\text { Ite } \\
\mathrm{m} 3\end{array}$ & $\begin{array}{l}0,85 \\
8\end{array}$ & $\begin{array}{l}0,19 \\
5 \\
\end{array}$ & Valid \\
\hline
\end{tabular}

Berdasarkan tabel di atas dapat dilihat bahwa setiap indikator pertanyaan memiliki $r$ hitung lebih besar dari $r$ tabel. Nilai $r$ tabel yang digunakan ialah 0,195 dnegan tingkat signifikansi sebsar 5\% menggunakan uji dua sisi (two-tailed).

\section{Hasil Uji Reliabilitas}

Uji reliabilitas berguna untuk mengukur sejauh mana pengukuran dari suatu tes pengujian tetap konsisten atau tidak setelah dilakukan berulang-ulang terhadap subjek dan dalam kondisi yang sama. 
Septiani Riwanti \& Dwi Kartikasari, Persepsi Antara Tenaga Kerja Pendatang...

Variabel dikatakan reliable apabila memberikan nilai a>0.60 (Sujarweni, 2008).

\begin{tabular}{|c|c|c|c|c|}
\hline \multicolumn{5}{|c|}{ Reliabilitas } \\
\hline Variabel & $\begin{array}{l}\text { Nof } \\
\text { Item }\end{array}$ & $\begin{array}{c}\text { Alpha } \\
\text { Cronb } \\
\text { ach }\end{array}$ & $\begin{array}{c}\text { Cut of } \\
\text { Alpha } \\
\text { Cronbac } \\
h \\
\end{array}$ & $\begin{array}{c}\text { Kesimpula } \\
\mathbf{n}\end{array}$ \\
\hline $\begin{array}{l}\text { Lapangan } \\
\text { Pekerjaan }\end{array}$ & 4 & 0,689 & 0,60 & Reliabel \\
\hline $\begin{array}{l}\text { Upah } \\
\text { Rendah }\end{array}$ & 4 & 0,645 & 0,60 & Reliabel \\
\hline $\begin{array}{l}\text { Mencari } \\
\text { Modal } \\
\end{array}$ & 3 & 0,615 & 0,60 & Reliabel \\
\hline $\begin{array}{l}\text { Kebutuhan } \\
\text { Hidup }\end{array}$ & 3 & 0,637 & 0,60 & Reliabel \\
\hline $\begin{array}{l}\text { Kesempata } \\
\text { n Kerja }\end{array}$ & 4 & 0,684 & 0,60 & Reliabel \\
\hline $\begin{array}{l}\text { Upah } \\
\text { Tinggi }\end{array}$ & 3 & 0,674 & 0,60 & Reliabel \\
\hline Jarak & 4 & 0,944 & 0,60 & Reliabel \\
\hline $\begin{array}{l}\text { Kesamaan } \\
\text { Budaya }\end{array}$ & 3 & 0,707 & 0,60 & Reliabel \\
\hline
\end{tabular}

Berdasarkan tabel di atas menunjukkan bahwa semua variabel memiliki nilai Cronbach's Alpha lebih dari 0,60 sehingga dapat disimpulkan bahwa lapangan pekerjaan, upah rendah, mencari modal, kebutuhan hidup, kesempatan kerja, upah tinggi, jarak dan kesamaan budaya ialah reliabel.

\section{Hasil Uji Deskriptif}

Statistik deskriptif digunakan oleh peneliti dalam penelitian ini untuk memberi gambaran dari suatu data yang dapat dillihat dari nilai minimum, maksimum, mean dan standar deviasi. Hasil statistik deskriptif dalam penelitian ini menggunakan program SPSS 20. Hasil perbedaan statistik antara laki-laki dan perempuan ialah sebagai berikut:

1. Rata-rata Responden laki-laki dan perempuan menjawab setuju dengan persentase perempuan $46 \%$ dan laki-laki $64 \%$ terhadap sektor pertanian,perkebunan, perikanan, industri yang ada di daerah asal tidak mampu menyerap tenaga kerja dengan banyak..

2. Rata-rata Responden laki-laki dan perempuan menjawab setuju dengan persentase $56 \%$ terhadap tingkat pendidikan memperngaruhi dalam memperoleh pekerjaan di daerah asal.

3. Rata-rata Responden laki-laki dan perempuan menjawab setuju dengan persentase perempuan $50 \%$ dan laki-laki 54\% terhadap sektor pertanian dan perkebunan yang bergantung pada musim, tidak memberikan keberlanjutan masyarakat dalam bekerja.

4. Rata-rata Responden laki-laki dan perempuan menjawab tidak setuju dengan persentase perempuan $36 \%$ dan laki-laki $\quad 54 \% \quad$ terhadap keahlian/ketrampilan yagn dimiliki menjadi penghambat dalam memperoleh pekerjaan yang ada di daerah asal.

5. Rata-rata Responden laki-laki dan perempuan menjawab setuju dengan persentase perempuan $48 \%$ dan laki-laki $36 \%$ terhadap bedaran upah di daerah asal masih rendah dibandingkan besaran upah pekerja di Batam.

6. Rata-rata Responden perempuan menjawab sangat setuju dengan persentase $38 \%$ sedangkan responden laki-laki menjawab setuju dengan persentase $50 \%$ terhadap pendapatan yang diterima di daerah asal tidak sebanding dengan pekerjaan yang dilakukan.

7. Rata-rata Responden perempuan menjawab sangat setuju dengan persentase $34 \%$ dan responden laki-laki menjawab tidak setuju dengan persentase $52 \%$ terhadap pendapatan yang diperoleh di daerah asal tidak mencukupi kebutuhan sehari-hari.

8. Rata-rata Responden laki-laki dan perempuan menjawab tidak setuju dengan persentase perempuan $44 \%$ dan laki-laki $48 \%$ terhadap jam kerja di daerah asal yang tidak menentu.

9. Rata-rata Responden laki-laki dan perempuan menjawab setuju dengan persentase perempuan $48 \%$ dan laki-laki 42\% terhadap alasan bekerja di Batam karena ingin mencari modal untuk membuat usaha di daerah asal. 
10. Rata-rata Responden laki-laki dan perempuan menjawab setuju dengan persentase perempuan $60 \%$ dan laki-laki $70 \%$ terhadap pendapatan yang diperoleh di Batam cukup untuk dijadikan modal usaha.

11. Rata-rata Responden laki-laki dan perempuan menjawab setuju dengan persentase perempuan $46 \%$ dan laki-laki $40 \%$ terhadap kembalinya para pekerja pendatang ke daerah asal jika sudah mampu membuka usaha di daerah asalnya.

12. Rata-rata Responden laki-laki dan perempuan menjawab setuju dengan persentase $44 \%$ terhadap kebutuhan yang belum terpenuhi ketika masih bekerja di daerah asal.

13. Rata-rata Responden laki-laki dan perempuan menjawab setuju dengan persentase perempuan $58 \%$ dan laki-laki $56 \%$ terhadap alasan bekerja di Batam untuk memenuhi kebutuhan hidup keluarga di daerah asal.

14. Rata-rata Responden laki-laki dan perempuan menjawab setuju dengan persentase perempuan $48 \%$ dan laki-laki $56 \%$ terhadap tercukupnya kebutuhan hidup semenjak bekerja di Batam dan bisa menabung.

15. Rata-rata Responden perempuan menjawab setuju dengan persentase $40 \%$ dan responden laki-laki menjawab tidak setuju dengan persentase $46 \%$ terhadap kesempatan memperoleh pekerjaan di Batam yang sangat besar.

16. Rata-rata Responden perempuan menjawab tidak setuju dengan persentase $32 \%$ dan responden laki-laki menjawab setuju dengan persentase $38 \%$ terhadap ketidak harusan untuk memiliki keahlian khusus ketika bekerja di Batam.

17. Rata-rata Responden laki-laki dan perempuan menjawab setuju dengan persentase perempuan $42 \%$ dan laki-laki $53 \%$ terhadap pengurusan administrasi untuk menjadi tenaga kerja di batam yang lebih mudah dibandingkan dengan daerah lain.
18. Rata-rata Responden perempuan menjawab setuju dengan peresentase $40 \%$ dan responden laki-laki menjawab tidak setuju dengan persentase 56\% terhadap dengan tingkat pendidikan minimal SMA/Sederajat sudah bisa memperoleh pekerjaan di Batam.

19. Rata-rata Responden laki-laki dan perempuan menjawab setuju dengan persentase perempuan $46 \%$ dan laki-laki $66 \%$ terhadap tingkat upah tenaga kerja batam yang cukup tinggi dibandingkan daerah lain di Indonesia.

20. Rata-rata Responden perempuan menjawab setuju dengan persentase $64 \%$ dan responden laki-laki menjawab tidak setuju dengan persentase $72 \%$ terhadap upah yang diterima saat bekerja di Batam sudah sesuai dengan jenis pekerjaan yang dilakukan.

21. Rata-rata Responden laki-laki dan perempuan menjawab setuju dengan persentase perempuan $62 \%$ dan laki-laki $64 \%$ terhadap upah yang diterima menjadi tenaga kerja pendatang sudah mencukupi kebutuhan keluarga.

22. Rata-rata Responden perempuan menjawab setuju dengan persentase $46 \%$ dan responden laki-laki menjawab tidak setuju dengan persentase $50 \%$ terhadap Batam menjadi kota tujuan dalam menjadi tenaga kerja pendatang karena jarak yang dekat dengan daerah asal sehingga untuk menjadi tenaga kerja tidak harus ke luar negeri.

23. Rata-rata Responden perempuan menjawab setuju dengan persentase $50 \%$ dan responden laki-laki menjawab tidak setuju dengan persentase $48 \%$ terhadap jarak yang dekat mempengaruhi biaya yang dikeluarkan menjadi sedikit.

24. Rata-rata Responden perempuan menjawab setuju dengan persentase $54 \%$ dan responden laki-laki menjawab tidak setuju dengan persentase $40 \%$ terhadap jarak yang dekat memudahkan dalam memilih transportasi apapun untuk sampai ke Batam. 
Septiani Riwanti \& Dwi Kartikasari, Persepsi Antara Tenaga Kerja Pendatang...

25. Rata-rata Responden perempuan menjawab setuju dengan persentase $58 \%$ dan responden laki-laki menjawab tidak setuju dengan persentase $46 \%$ terhadap faktor jarak yang dekat dapat meminimalisasi waktu untuk sampai ke Batam.

26. Rata-rata Responden laki-laki dan perempuan menjawab setuju dengan persentase perempuan $50 \%$ dan laki-laki $58 \%$ terhadap bahasa Indonesia tidak menjadi penghambat dalam bekerja di Batam karena masih dalam 1 negara Indonesia.

27. Rata-rata Responden perempuan menjawab setuju dengan persentase $50 \%$ dan responden laki-laki menjawab tidak setuju dengan persentase $40 \%$ terhadap kehidupan sosial di Batam tidak jauh berbeda dengan kehidupan sosial di daerah asal.

28. Rata-rata Responden laki-laki dan perempuan menjawab setuju dengan persentase perempuan $52 \%$ dan laki-laki $38 \%$ terdapat struktur budaya Batam yang tidak jauh berbeda dengan daerah asal sehingga memudahkan dalam beradaptasi dan bersosialisasi.

\section{Hasil Uji Normalitas}

Uji normalitas yang digunakan dalam penelitian ini adalah Kolmogorov Smirnov. Pengujian normalitas ini dilakukan dengan syarat jika nilai Kolmogorov Smirnov $Z$ dan Asymp. Sig > atau $=0,05$ maka data berdistribusi normal dan sebaliknya.

\begin{tabular}{|l|l|l|l|}
\hline $\begin{array}{l}\text { Uji } \\
\text { Normalita }\end{array}$ & Variabel & $\begin{array}{l}\text { Unstandari } \\
\text { zed } \\
\text { Residual }\end{array}$ & $\begin{array}{l}\text { Keteranga } \\
\mathrm{n}\end{array}$ \\
\hline $\begin{array}{l}\text { Symp.sig } \\
\text { (2-tailed) }\end{array}$ & $\begin{array}{l}\text { Lapangan } \\
\text { Pekerjaan }\end{array}$ & 0,678 & $\begin{array}{l}\text { Data } \\
\text { Berdistrib } \\
\text { usi } \\
\text { Normal }\end{array}$ \\
\hline $\begin{array}{l}\text { Symp.sig } \\
\text { (2-tailed) }\end{array}$ & $\begin{array}{l}\text { Upah } \\
\text { Rendah }\end{array}$ & 0,599 & $\begin{array}{l}\text { Data } \\
\text { Berdistrib } \\
\text { usi } \\
\text { Normal }\end{array}$ \\
\hline $\begin{array}{l}\text { Symp.sig } \\
\text { (2-tailed) }\end{array}$ & $\begin{array}{l}\text { Mencari } \\
\text { Modal }\end{array}$ & 0,298 & $\begin{array}{l}\text { Data } \\
\text { Berdistrib }\end{array}$ \\
\hline
\end{tabular}

\begin{tabular}{|l|l|l|l|}
\hline & & & $\begin{array}{l}\text { usi } \\
\text { Normal }\end{array}$ \\
\hline $\begin{array}{l}\text { Symp.sig } \\
\text { (2-tailed) }\end{array}$ & $\begin{array}{l}\text { Kebutuhan } \\
\text { Hidup }\end{array}$ & 0,104 & $\begin{array}{l}\text { Data } \\
\text { Berdistrib } \\
\text { usi } \\
\text { Normal }\end{array}$ \\
\hline $\begin{array}{l}\text { Symp.sig } \\
\text { (2-tailed) }\end{array}$ & $\begin{array}{l}\text { Kesempata } \\
\text { n Kerja }\end{array}$ & 0,480 & $\begin{array}{l}\text { Data } \\
\text { Berdistrib } \\
\text { usi } \\
\text { Normal }\end{array}$ \\
\hline $\begin{array}{l}\text { Symp.sig } \\
\text { (2-tailed) }\end{array}$ & $\begin{array}{l}\text { Upah } \\
\text { Tinggi }\end{array}$ & 0,123 & $\begin{array}{l}\text { Data } \\
\text { Berdistrib } \\
\text { usi } \\
\text { Normal }\end{array}$ \\
\hline $\begin{array}{l}\text { Symp.sig } \\
\text { (2-tailed) }\end{array}$ & Jarak & 0,052 & $\begin{array}{l}\text { Data } \\
\text { Berdistrib } \\
\text { usi } \\
\text { Normal }\end{array}$ \\
\hline $\begin{array}{l}\text { Symp.sig } \\
\text { (2-tailed) }\end{array}$ & $\begin{array}{l}\text { Kesamaan } \\
\text { Budaya }\end{array}$ & 0,219 & $\begin{array}{l}\text { Data } \\
\text { Berdistrib } \\
\text { usi } \\
\text { Normal }\end{array}$ \\
\hline
\end{tabular}

\section{Hasil Uji Hipotesis}

Uji hipotesis dalam penelitian ini menggunakan alat uji Independent Sample T Test. Penentuan kesimpulannya berdasarkan signifikasi sebagai berikut:

3. Signifikansi $<0.05$, maka Ho ditolak dan Ha diterima

4. Signifikansi >0.05, maka Ho diterima dan Ha ditolak

Hasil uji hipotesis pertama menunjukkan bahwa perbedaan persepsi antara laki-laki dan perempuan terhadap lapangan pekerjaan diperoleh nilai rata-rata responden perempuan sebesar 11,98 dan responden laki-laki 11,32 serta nilai signifikansi responden perempuan sebesar 0,117 dan responden laki-laki 0,118 yang berarti Ho diterima dan $\mathrm{Ha}$ ditolak. Kebermaknaan ini mengandung implikasi bahwa tidak terdapat perbedaan persepsi antara tenaga kerja pendatang laki-laki dan perempuan terhadap lapangan pekerjaan. Selanjutnya hasil uji hipotesis kedua menunjukkan bahwa perbedaan persepsi antara laki-laki dan perempuan terhadap upah rendah diperoleh nilai rata-rata responden perempuan sebesar 12,04 dan 
responden laki-laki 11,20 serta nilai signifikansi responden perempuan sebesar 0,054 dan responden laki-laki 0,055 yang berarti Ho diterima dan Ha ditolak. Kebermaknaan ini mengandung implikasi bahwa tidak terdapat perbedaan persepsi antara tenaga kerja pendatang laki-laki dan perempuan terhadap upah rendah.

Selanjutnya hasil uji hipotesis ketiga menunjukkan bahwa perbedaan persepsi antara laki-laki dan perempuan terhadap mencari modal diperoleh nilai rata-rata responden perempuan sebesar 9,10 dan responden laki-laki 8,86 serta nilai signifikansi 0,537 yang berarti Ho diterima dan $\mathrm{Ha}$ ditolak. Kebermaknaan ini mengandung implikasi bahwa tidak terdapat perbedaan persepsi antara tenaga kerja pendatang laki-laki dan perempuan terhadap mencari modal. Kemudian hasil uji hipotesis ketiga menunjukkan bahwa perbedaan persepsi antara laki-laki dan perempuan terhadap kebutuhan hidup diperoleh nilai rata-rata responden perempuan sebesar 9,44 dan responden laki-laki 8,74 serta nilai signifikansi 0,025 yang berarti Ho ditolak dan $\mathrm{Ha}$ diterima. Kebermaknaan ini mengandung implikasi bahwa terdapat perbedaaan persepsi anatar tenaga kerja pendatang laki-laki dan perempuan terhadap kebutuhan hidup.

Lalu hasil uji hipotesis kelima menunjukkan bahwa perbedaan persepsi antara laki-laki dan perempuan terhadap kesempatan kerja diperoleh nilai rata-rata responden perempuan sebesar 10,74 dan responden laki-laki 9,64 serta nilai signifikansi responden perempuan sebesar 0,028 dan responden laki-laki 0,029 yang berarti Ho ditolak dan $\mathrm{Ha}$ diterima. Kebermaknaan ini mengandung implikasi bahwa terdapat perbedaan persepsi antara tenaga kerja pendatang laki-laki dan perempuan terhadap kesempatan kerja. Kemudian hasil uji hipotesis keenam menunjukkan bahwa perbedaan persepsi antara laki-laki dan perempuan terhadap upah tinggi diperoleh nilai rata-rata responden perempuan sebesar 9,28 dan responden laki-laki 8,32 serta nilai signifikansi 0,001 yang berarti Ho ditolak dan $\mathrm{Ha}$ diterima. Kebermaknaan ini mengandung implikasi bahwa terdapat perbedaan persepsi antara tenaga kerja pendatang laki-laki dan perempuan terhadap upah tinggi.

Selanjutnya hasil uji hipotesis ketujuh menunjukkan bahwa perbedaan persepsi antara laki-laki dan perempuan terhadap jarak diperoleh nilai rata-rata responden perempuan sebesar 11,30 dan responden laki-laki 9,28 serta nilai signifikansi 0,000 yang berarti Ho ditolak dan $\mathrm{Ha}$ diterima. Kebermaknaan ini mengandung implikasi bahwa terdapat perbedaan persepsi antara tenaga kerja pendatang laki-laki dan perempuan terhadap jarak. Lalu hasil uji hipotesis kedelapan menunjukkan bahwa perbedaan persepsi antara laki-laki dan perempuan terhadap kesamaan budaya diperoleh nilai rata-rata responden perempuan sebesar 9,42 dan responden lakilaki 8,62 serta nilai signifikansi 0,032 yang berarti Ho ditolak dan $\mathrm{Ha}$ diterima. Kebermaknaan ini mengandung implikasi bahwa terdapat perbedaan persepsi antara tenaga kerja pendatang laki-laki dan perempuan terhadap kesamaan budaya.

\section{KESIMPULAN DAN SARAN Kesimpulan}

Berdasarkan hasil dari analisis dan pembahasan yang telah diuraikan dalam penelitian mengenai perbedaan persepsi anatar tenaga kerja pendatang lak-laki dan perempuan terhadap push and pull factors, maka diperolah kesimpulan sebagai berikut:

1. Tidak terdapat perbedaan persepsi antara tenaga kerja pendatang laki-laki dan perempuan terhadap lapangan pekerjaan (push factor).

2. Tidak terdapat perbedaan persepsi antara tenaga kerja pendatang laki-laki dan perempuan terhadap upah rendah (push factor).

3. Tidak terdapat perbedaan antara tenaga kerja pendatang laki-laki dan perempuan terhadap mencari modal (push factor). 
Septiani Riwanti \& Dwi Kartikasari, Persepsi Antara Tenaga Kerja Pendatang...

4. Terdapat perbedaan persepsi antara tenaga kerja pendatang laki-laki dan perempuan terhadap kebutuhan hidup (push factor).

5. Terdapat perbedaan persepsi antara tenaga kerja pendatang laki-laki dan perempuan terhadap kesempatan kerja (pull factor).

6. Terdapat perbedaan persepsi antara tenaga kerja pendatang laki-laki dan perempuan terhadap upah tinggi (pull factor).

7. Terdapat perbedaan persepsi antara tenaga kerja luar pendatang laki-laki dan perempuan terhadap jarak

Terdapat perbedaan antara tenaga kerja pendatang laki-laki dan perempuan terhadap kesamaan budaya (pull factor).

\section{Saran}

Berdasarkan kesimpulan pada penelitian ini, penulis menyampaikan beberapa saran untuk peneliti selanjutnya yakni:

1. Penelitian selanjutnya sebaiknya menambahkan jumlah sampel dna menggunakan rumus pengambilan sampel yang lebih tepat.

2. Penelitian selanjutnya diharapkan menambahkan variabel.

3. Penelitian selanjutnya diharapkan dapat menggunakan metode wawancara kepada responden untuk mendukung kuesioner.

4. Penelitian selanjutnya diharapkan dapat menambahkan pernyataan-pernyataan yang lebih baik.

5. Penelitian selanjutnya diharapkan dapat mengidentifikasi keseluruhan karakteristik responden.

6. Untuk Dinas Ketenagakerjaan Batam agar dapat menyajikan informasi/data yang detail terkait jumlah tenaga kerja pendatang dari luar Batam

\section{KETERBATASAN}

Pada kenyataannya penelitian ini masih memiliki beberapa keterbatasan. Dengan adanya keterbatasan ini, peneliti berharap agar dapat dilakukan perbaikan untuk peneliti di masa yang akan datang.

Adapun keterbatasan dalam penelitian ini antara lain:

1. Pada kuesioner tidak mengidentifikasi karakteristik responden secara detail.

2. Pendapatan responden hanya dilihat dari upah yang mereka terima setiap bulannya,tanpa mengetahui biaya hidup dan sebagainya.

3. Penyebaran dilakukan dengan memberikan kuesioner berupa kertas, namun peneliti tidak dapat melakukan wawancara karena keterbatasan waktu sehingga memerlukan pihak lain dalam menyebarkannya.

4. Data yang detail mengenai jumlah tenaga kerja pendatang tidak dapat ditemukan karena pada Dinas Ketenagakerjaan Batam hanya memberikan data dengan tenaga kerja pendatang laki-laki perempuan secara umum.

\section{DAFTAR PUSTAKA}

(2018, Agustus 28). Diambil kembali dari Dinas Tenaga Kerja Pemerintah Kota Batam: https://disnaker.batam.go.id

Anggraini. (2009). Faktor-Faktor Yang Berhubungan Dengan Konsumsi Suplemen Vitamin dan Mineral pada Atlet Renang di Klub Renang Wilayah Jakarta Selatan. FKM UI.

Anif, \& S. (2017). Mobilitas Pekerja Malaysia (Strategi Masyarakat Desa Jawa Tengah Mengatasi Kemiskinan dan Biaya Pendidikan. THE 5TH URECOL PROCEEDIN.

Armoyu. (2009). Beragam Perilaku Migrasi Tenaga Kerja pada Daerah Tertinggal di Jawa Timur Melalui Pendekatan Hedonic. FEB UNAIR.

Fattah, \& Sanusi. (2008). Ilmu pengetahuan sosial : untuk SMP/ MTs kelas VIII. Jakarta: Pusat Perbukuan Departemen Pendidikan Nasional.

Felicidad. (2016). Push And Pull Factors Tenaga Kerja Filiphina Migrasi di Kerajaan Bahrain. International 
Advanced Research Journal Science, Teknik dan Teknologi.

Gusman, \& I. (2015). Push And Pull Factors of Indonesian Women Migrant Workers from Indramayu (West Java) to Work Abroad. Mediterranean Journal of Social Science.

Kainth. (2015). Push and Pull Factors of Migration: A Case Study of Brick Kiln.

Mulyana, C. (2018, July 4). 2018 5\%, 2019 Pertumbuhan Ekonomi Batam Ditargetkan 7\%. Diambil kembali dari batampos.co.id: https://batampos.co.id/2018/07/04/20 18-5-2019-pertumbuhan-ekonomibatam-ditargetkan-7/

Munanto. (2016). Analisis Faktor-Faktor Yang Mempengaruhi Tenaga Kerja di Jawa Tengah Tahun 2014. Jurnal Ekonomi.

Primawati. (2011). Faktor Ekonomi Sebagai Alasan Migrasi Internasional ke Malaysia. INSANI.

Puspitawati. (2013). Konsep, Teori dan Analisis Gender. Bogor: PT. IPB Press.

Republik Indonesia, D. (2003). UU No. 3 Tahun $2003 \quad$ Tentang Ketenagakerjaan. Jakarta.

Santoso. (2017). Menguasai Statistik SPSS 24. Jakarta: PT. Elex Media Komputindo.

Simamora, A. (2018, September 18). Jumlah Pencari Kerja Asal Luar Batam Ternyata Banyak, Jumlah Mencapai 25 Ribu Lebih. Diambil kembali dari Tribunbatam.id: http://batam.tribunnews.com/2018/09 /18/jumlah-pencari-kerja-asal-luarbatam-ternyata-banyak-jumlahnyamencapai-25-ribu-lebih

Statistik, B. P. (2018, September 1). Diambil kembali dari BADAN PUSAT STATISTIK PROVINSI KEPULAUAN RIAU:
Statistik, B. P. (2018, September 1). Jumlah Penduduk Kota Batam. Diambil kembali dari BADAN PUSAT STATISTIK KOTA BATAM: https://batamkota.bps.go.id

Statistik, B. P. (2018, Agustus 27). Jumlah Tenaga Kerja di Kepulauan Riau. Diambil kembali dari BADAN PUSAT STATISTIK: https://bps.go.id

Sugiyono. (2013). Statistika Untuk Penelitian. Bandung: CV. ALFABETA.

Susilo. (2016). Beberapa Faktor Yang Menentukan TKI Dalam Memilih Negara Tujuan Sebagai Tempat Bekerja, Studi di Desa Aryojeding Kabupaten Tulungagung. Jurnal Pendidikan Geografi.

Uma, Cha, \& Yui. (2018, Agustus 27). Sulit Mencari Kerja di Batam. Diambil kembali dari batampos.co.id: https://batampos.co.id

Wahyono, T. (2012). Analisis Statistik Mudah Dengan SPSS 20. Jakarta: PT. Elex Media Komputindo. www.https://kepri.bps.go.id 